\title{
PENYESUAIAN DIRI ANAK LUAR BIASA (STUDI KASUS ADE IRAWAN, JUARA PIANIS TUNANETRA INDONESIA)
}

\author{
Fitri Aulia ${ }^{1}$
}

\begin{abstract}
Adjustment is the ability of individuals to associate with them self and environment. Children have experience growth and development in her both physically and mentally, covers an area of motor/biological, cognitive, and emotional development/affective/social. Growth in this area lasted three continuous and sustainable for the human growth process. During the process, begin a familiar term exceptional children, because of different developmental processes. In mental health, the children will remain outstanding face demand adjustment interact, work, education, married, gave birth to off spring. The children are exceptional (1) Child mental disorders, include a) children who have unusually high intellectual capacity (intellectually superior), and $b$ ) the kids are slow to learn (Mentally retarded), (2) sensory disorders, including children with a) damage to hearing (auditory impairments), also known as hearing impairment, b) impaired vision (visual impairments), also known as the blind, (3) communication disorders, a) learning disabilities (learning disability), b) in speech and language disorders (speech and language impairments), (4) behavioral disorders, including: a) emotional disorders, b) Incompatibility of social behavior or tunalaras (social maladjustment), (5) tunagrahita or severe disability, covering a variety of disabilities such as CP combination with mental retardation, visual impairments with mental retardation. Focus questionsis What is the process through which the development of Ade Irawan in life. Qualitative research methods, with secondary data from a number of sites biography Ade Irawan, analyzing various body language, personal statements subject, as well as the statements of parents, and people nearby. Results showed that developments Ade Irawan is formed as follows: (1) parental support, (2) high level of intelligence, (3) music talent, forming a positive self concept, (4) conversion of audio viasualisasi dominant senses, (5) the character general visual impairment: high alert attitude on the new people, brave and critical.
\end{abstract}

Keywords: Adaptation, Excellent child, Blind people.

\section{A. Pendahuluan}

Proses penyesuaian diri adalah proses belajar dari lingkungan. Sigmund Freud mengemukakan tentang pentingnya pengalaman pada

1 Mahasiswa Pascasarjana Universitas Islam Negeri (UIN) Sunan Kalijaga Yogyakarta 
fase anak-anak, yang akan berpengaruh pada masa remaja hingga dewasa. (Ricardo Nelson, Jones, 2011: 70)

Psikologi perkembangan membagi fase anak-anak menjadi empat, yakni: (1) masa bayi, (0-2 tahun), (2) masa anak awal (2-6 tahun) sering disebut masa prasekolah, (3) masa anak lanjut (6-12/13 tahun), disebut masa anak sekolah dasar, (4) masa remaja (13-18 tahun). Pada masa ini, anak menjadi matang secara seksual dan merupakan masa peralihan antara masa anak dan masa dewasa. (Utami Munandar, 1992: 1)

Jean Piaget membagi kecerdasan kognitif anak-anak menjadi 3 fase yakni: (1) fase sensori motorik (0-2 tahun) bayi memperoleh pengetahuan tentang dunia dari tindakan-tindakan fisik yang mereka lakukan. (2) fase pre operasional (2-7 tahun), anak mulai belajar dari gambaran-gambaran mental atau imajinasi untuk memahami dunianya, (3) operasional concret, (7-11 tahun), anak mampu berpikir logis tetang kejadian konkret di sekelilingnya. (Jhon W. Santrock, 2007: 246) Menurutnya faktor yang mempengaruhi perkembangan kognitif anak adalah, (a) faktor lingkungan, (b) faktor intuisi (kemampuan mempersepsikan pengetahuan dari dalam diri). (Desmita, 2005: 46) Albert Bandura meyakini setiap individu belajar dengan cara mengamati orang lain (observational learning), dimana tindakan individu banyak dihasilkan dari proses melihat dan mengamati lingkungan, kemudian individu akan membuat penilaian. (Fridman dan Miriam, 2006: 277)

Berdasarkan penjelasan tersebut, Piaget dan Bandura sepakat bahwa lingkungan memiliki pengaruh yang besar dalam perkembangan anak. Meskipun Piaget juga mempercayai adanya intuisi atau bakat bawaan.

Anak tunanetra adalah bagian dari anak luar biasa, mereka memiliki peran yang sama dengan anak normal lainnya dalam kehidupan. sesuai hasil survey kesehatan indera penglihatan dan pendengaran sejak tahun 1993-1996, Farida Sirlan selaku Guru Besar ilmu Kesehatan Mata, Fakultas Kedokteran UI mengatakan, angka gangguan penglihatan masyarakat Indonesia sudah mencapai 1,5\% atau sekitar 3,6 juta jiwa dari 245 juta penduduk Indonesia.

Besarnya angka tunanetra tersebut, memang diharapkan menumbukan kesadaran pada masyarakat tentang arti kepedulian. Ikut serta dalam membina mereka adalah bagian yang sangat penting, membina disini berarti dalam kemandirian di tengah-tengah kekurangan 
fisik yang mereka alami. Salah satu dari tunanetra yang ada di negara ini adalah Ade Irawan, remaja yang kini berusia 20 tahun ini memiliki prestasi yang cukup membanggakan bagi Indonesia.

\section{B. Pengertian Anak Luar Biasa}

Yustinus menggunakan istilah anak luar biasa untuk menjelaskan anak-anak yang memiliki kemampuan intelektual dan bakat yang luar biasa, serta untuk menjelaskan anak-anak yang cacat/tidak normal. Lebih lanjut ia mendefinisikan anak tergolong luar biasa, yang memiliki karakter berikut ini: (1) ciri-ciri khas mental, (2) kemampuan-kemampuan panca indera, (3) kemampuan-kemampuan komunikasi, (4) tingkah laku sosial, (5) dan ciri-ciri khas fisik. (Yustinus Semiun, 2006: 237)

Ellah Siti Cholidah juga mengemukakan, bahwa anak luar biasa adalah anak yang menyimpang dari rata-rata anak normal, baik menyimpang ke atas maupun ke bawah dari kriteria normal dalam hal karakteristik mental, kemampuan-kemampuan sensoris, karakteristik neuromotor atau fisik, perilaku sosial serta emosional, kemampuan berkomunikasi, maupun gabungan dari berbagai variable tersebut sejauh ia memerlukan modifikasi pelaksanaan sekolah dalam bentuk pelayanan pendidikan khusus atau pendidikan luar biasa (special education) untuk mengembangkan kapasitasnya secara maksimum. (Ellah Siti Chalidah, 2005: 12)

Jika digambarkan dalam bentuk kurva, posisi anak-anak luar biasa akan nampak seperti gambar berikut:

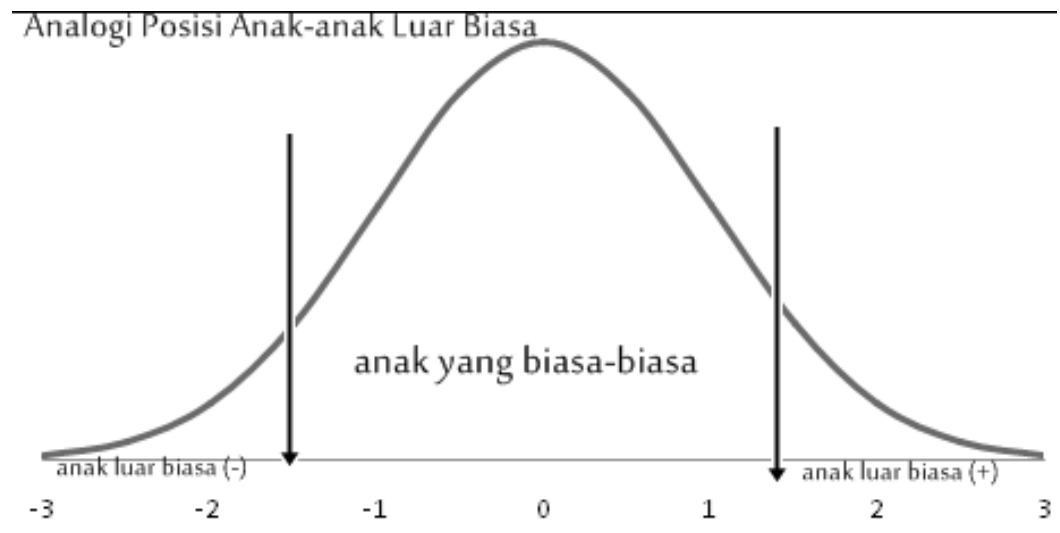


Dapat disimpulkan bahwa anak luar biasa adalah anak-anak yang mengalami proses perkembangan yang tidak seperti anak-anak pada umumnya, bisa lebih cepat, bisa pula lebih lambat.

\section{Faktor-faktor yang Mempengaruhi Perkembangan Anak Luar Biasa}

Ada beberapa faktor yang mempengaruhi cepat/lambatnya masa tumbuh kembang anak, diantaranya genetika, hereditas, temperamental, intelektual, kesehatan dan nutrisi, budaya, pengaruh lingkungan, serta pengalaman-pengalaman khusus dari masing-masing tahap perkembangan yang dialami anak. (Utami Munandar, 1992: 18)

Secara lebih rinci, faktor-faktor penyebab anak luar biasa dibagi kedalam 3 tahap, yaitu saat di kandungan, saat kelahiran, dan postnatal/ pasca kelahiran, seperti dijelaskan berikut ini:

1) Faktor pra kelahiran atau saat di dalam kandungan

a. Kelainan hereditas atau bawaan yang merupakan faktor genetika

b. Keracunan pada saat di dalam kandungan

c. Faktor psikologis

d. Infeksi di dalam kandungan seperti rubella (campak) pada ibu

e. Kekurangan gizi

f. Berbagai penyakit yang disebabkan virus, seperti shupillis (kepala besar)

g. Kerusakan biokimia yang menyebabkan abnormalitas kromosom

h. Faktor khusus

2) Faktor saat dilahirkan (natal)

a. Pendarahan di otak

b. Asfiksia (gangguan pernapasan pada pengangkutan oksigen ke jaringan; kekurangan zat asam pada darah)

c. Kerusakan bagian otak, yang diakibatkan terkena penjepit

d. Lahir dengan vacuum 

e. Sesak napas
f. Prematuritas

3) Faktor setelah dilahirkan (postnatal)
a. Infeksi
b. Encephalitis
c. Meningitis
d. Malturisi
e. Disebabkan kecelakaan
f. Perkembangan yang terlambat (Ellah Siti Chalidah, 2005: 1213)

Faktor pre natal juga bisa disebabkan karena gangguan kromosom. Manusia memiliki 22 kromosom biasa (autosom) dan satu kromosom jenis kelamin. Kromosom yang terpanjang diberi nomor 1, diikuti oleh yang kurang panjang, sampai no 22; kromosom jenis kelamin pria disebut $Y$, sedangkan untuk wanita disebut $X$. kromosom-kromosom itu juga dikelompokkan. Kelainan dapat terjadi pada kromosom, dapat pula pada gena. Apabila sel keturunan yang mempunyai kromosom atau gena berkelainan mendapat pembuahan dan selanjutnya berkembang menjadi bayi, maka kelainan ini akan ada pada bayi tersebut dan dapat mengakibatkan keluarbiasaan. (Suhaeni dan Edi Purwanto, 3)

Kelainan yang mengakibatkan keluarbiasaan banyak macamnya, diantaranya:

1) Trisomy: setelah mengalami pembuahan, kromosom inti sel kelamin akan berpasang-pasangan menjadi dua-dua, satu dari ayah dan satu dari ibu. Pada trisomi tampak ada kromosom yang berpasangpasangan bukan dua tetapi tiga, misalnya karena ditambah dari patahan kromosom lain. Maka anak yang terjadi dari trisomi memiliki kelainan-kelainan pada mulut, mata, kepala, tangan dan kecerdasan. Kelainan ini dikenal dengan down's syndrome

2) Anomaly kromosom kelompok D: setiap kromosom dapat mengalami kelainan. Adapun kelainan pada kromosom kelompok D berakibat pada anak berupa: kecil kepala, berkelainan mata, bertelinga terlalu bawah, belah langit-langit, berjari enam, dan kurang cerdas. Kelainan ini dikenal dengan nama ptau's syndrome. Anak-anak ini jelas membutuhkan pendampingan yang berbeda dari anak-anak lainnya. 
Fitri Aulia - Penyesuaian Diri Anak Luar Biasa ...

\section{Macam-Macam Anak Luar Biasa}

Adapun anak luar biasa, dibagi menjadi tiga yaitu:

\section{Sensori Motorik/biologis}

Penyimpangan dalam hal ketajaman sensorik antara lain: visual, auditif dan taktil (sentuhan/rabaan). Sedangkan penyimpangan fisik adalah gangguan gerak, kelumpuhan, kelayuan, kekacauan, gangguan koordinasi motorik kasar serta hilangnya sebagian atau seluruh anggota tubuh dan lain sebagainya. (Ellah Siti Chalidah, 2005: 9)

\section{Kognitif}

Cepat atau lambatnya kognitif seseorang sering diukur dengan tingkat intelegensinya. Seperti dinyatakan yustinus bahwa:

"Intelegensi adalah seperangkat ciri-ciri khas dan kemampuan kognitif yang tidak dapat diamati secara langsung." (Yustinus Semiun, 2006: 238)

Dari beberapa pendapat ilmuan tentang intelegensi, setidaknya pendapat Charles Spearman merupakan pendapat yang cukup tepat untuk menjawab makna intelegensi, yakni: kemampuan mental yang luas, yang meliputi fungsi kognitif, yang terdiri dari faktor umum $g$, serta faktor khusus untuk kemampuan tertentu s. Faktor $g$ adalah kemampuan setiap orang dalam mencapai keberhasilan atas semua tugas intelektual, sedangkan faktor $s$ adalah keunggulan seseorang dalam menyelesaikan tugas-tugas khusus. (Yustinus Semiun, 2006: 239)

Selanjutnya dengan menggunakan statistic, beberapa ilmuan seperti Revised Stanford, dan Wechselr mengadakan alat tes intelegensi yang dikenal dengan Binet Tes Of Intelligence (oleh Revised Stanford), dan Bellevue Scales (Form I, Form II, WAIS): Wechsler Intelligence Scale for Childern: Goodenough Drawing Test, dan Arthur Point Scale, dan yang paling sering digunakan adalah Terman Revision Of The Stanford Binet Dan Wechsler Scales, yang menghasilkan rentang tingkat intelegensi seperti berikut: (Yustinus Semiun, 2006: 243) 


\begin{tabular}{cc}
\hline Klasifikasi & Rentang IQ \\
\hline Genius & Diatas 140 \\
\hline Sangat superior & $120-140$ \\
Superior (normal atas) & $110-120$ \\
Normal atau rata-rata & $90-110$ \\
Normal bawah (bodoh) & $80-90$ \\
Garis batas & $70-80$ \\
Lemah mental: moron & $50-70$ \\
Imbisil & $25-50$ \\
Idiot & Di bawah 25 \\
\hline
\end{tabular}

Penyimpangan intelektual dalam bentuk kecerdasan di bawah ratarata (mentally retarded) atau intelektual luar biasa tinggi (intellectually superior). (Ellah Siti Chalidah, 2005: 9)

\section{a. Anak-anak Supernormal}

Tiga tingkat rentang IQ di atas sering disebut juga dengan anakanak supernormal. Rentang kecerdasannya adalah \pm 110 -200, dengan klasifikasi sebagai berikut: (Sutratinah Turtonegoro, 1984: 3)

1) Superior mewakili golongan yang memiliki $I Q \pm 110-125$

2) Gifted mewakili golongan yang memiliki IQ $\pm 125-140$

3) Genius mewakili golongan yang memiliki IQ $\pm 140-200$

\section{b. Anak-anak Reterdasi Mental}

Dari kolom rentang IQ di atas, IQ 70-80 merupakan batas anakanak yang dianggap luar biasa dengan sisi kogntif yang minus/ (-). Pada anak dengan IQ \pm 50 ke bawah, anak-anak memiliki kemampuan IQ di bawah 25 hingga dikenal dengan sebutan anak idiot.

Yustinus juga menjelaskan bahwa retardasi mental dikenal juga dengan istilah lemah mental, amentia, oligophrenia. Retardasi mental menimbulkan masalah sosial yang besar karena memerlukan saranasarana dan prosedur-prosedur pendidikan yang khusus. Fungsi sosial dan intelektualnya telah rusak (lemah). Retardasi mental dilihat sebagai suatu kondisi kronis dan tidak dapat dibah yang dimulai sebelum usia 18 tahun. (Yustinus Semiun, 2006: 265) 


\section{Emosi/afektif/sosial}

Pada perkembangan perilaku, anak-anak juga memiliki tingkat perkembangan yang berbeda-beda. Erycson pernah mengungkapkan ukuran ideal perkembangan emosi individu di tiap fase perkembangannya.

Anak luar biasa dengan kemampuan emosi yang terlambat juga banyak ditemukan. Kauffan mengungkapkan definisi tentang anakanak dengan gangguan perilaku, yakni:

"Anak-anak yang secara nyata dan menahan merespon lingkungan tanpa ada kepuasan pribadi namun masih dapat diajarkan perilaku-perilaku yang dapat diterima oleh masyarakat dan dapat memuaskan pribadinya."

Samuel A. Kirk berpendapat bahwa, menentukan gangguan perilaku pada anak sangatlah tidak mudah, karena hal itu dipengaruhi oleh sudut pandang orang yang mengamatinya. Hal itu dipicu oleh kenyataan bahwa hampir setiap anak mengungkapkan perilaku yang kadang tidak sesuai dengan usianya. Batasan normal atau tidak semua tergantung pada tingkat pengulang-ulangan dan jangka waktu terjadinya tindakan. (Samuel A. Kirk, 1991: 47)

Dalam UU Pendidikan bagi semua anak cacat memberikan batasan mengenai ketidakmampuan perilaku sebagai suatu keadaan yang menunjukkan salah satu atau lebih perilaku yang mencolok dalam jangka waktu yang panjang, seperti:

1) Suatu ketidakmampuan belajar yang sukar dijelaskan oleh proses indera otak atau faktor kesehatan

2) Suatu ketidakmampuan untuk membangun atau menjaga hubungan antara pribadi dengan teman sebaya atau guru

3) Jenis perilaku atau perasaan yagn tak layak di bawah keadaan normal

4) Suatu bentuk ketidakbahagiaan atau tekanan batin yang meluas.

5) Suatu kecenderungan pengembangan fisik yang dihubungkan dengan masalah pribadi atau sekolah (catatan federal) (Samuel A. Kirk, 1991: 47)

Quey menjelaskan tentang 4 pola perilaku yang menyimpang, yakni: 
1) Anak yang mengalami gangguan perilaku (conduct disorder), yang termasuk di dalamnya adalah anak yang hiperaktif, gelisah, dan hiperkinetik.

2) Anak yang cemas dan menarik diri (anxious withdrawn), adalah anak yang pemalu, penakut, suka menyendiri, peka dan penurut, anak yang ketergantungan dan mudah tertekan batin.

3) Dimensi ketidakmatangan (immaturity), yakni anak-anak yang tidak punya perhatian, lambat, tak berminat sekolah, pemalas, suka melamun dan pendiam.

4) Anak agresi sosialisasi (socialize-aggrressive), memiliki ciri yang bermasalah pada perilakunya, mereka biasanya membentuk gang, dan senang melakukan tindak kriminal. (Samuel A. Kirk, 1991: 52)

Selanjutnya dalam pandangan layanan pendidikan Kirk dan Gallagher mengklasifikasikan anak luar biasa menjadi lima yaitu:

1) Kelainan mental, meliputi anak-anak:
a. Yang memiliki kapasitas intelektual luar biasa tinggi (intellectually superior)
b. Yang lamban dalam belajar (mentally retarded)

2) Kelainan sensoris, meliputi anak-anak dengan:
a. Kerusakan pendengaran (auditory impairments), atau dikenal juga dengan tunarungu
b. Kerusakan penglihatan (visual impairments), dikenal juga dengan istilah tunanetra

3) Gangguan komunikasi meliputi:
a. Gangguan belajar (learning disability)
b. Gangguan dalam berbicara dan berbahasa (speech and language impairments)

4) Gangguan perilaku, meliputi:
a. Gangguan emosional (emotional disturbance), dan
b. Ketidaksesuaian perlaku sosial atau tunalaras (social maladjustment)


5) Tunagrahita atau cacat berat, meliputi macam-macam kombinasi kecacatan seperti $\mathrm{CP}$ dengan tunagrahita, tunanetra dengan tunagrahita. (Ellah Siti Chalidah, 2005: 19)

\section{E. Metode Penelitian}

\section{Jenis Penelitian dan Sumber Data}

Pada dasarnya, penelitian ini adalah penelitian pustaka (Library Research) yang menekankan kekuatan menganalisis data pada sumber yang ada. Sumber utama yang digunakan adalah data sekunder, yakni berupa video dan artikel, dari situs dan media lain yang memuat riwayat hidup subjek. Data tersebut kemudian diinterpretasikan secara jelas dan mendalam untuk menghasilkan tesis dan antitesis. (Abdurrahman Soejono, 1999: 14)

\section{Metode Pengumpulan Data dan Analisis}

Metode pengumpulan data pada penelitian ini adalah 1) observasi dan telaah dokumen. Observasi yang dilakukan adalah observasi tak langsung, yang disandarkan pada sejumlah media baik tulisan maupun audio visual. 2) telaah dokumen, yang berisi prestasi dan biografi subjek.

Analisis yang digunakan adalah Analisis Isi (Content Analisys) yaitu tehnik apapun yang digunakan untuk menarik kesimpulan melalui usaha untuk menemukan karakteristik pesan, dan dilakukan secara objektif dan sistematis. (Abdurrahman Soejono, 1999: 14) Berdasarkan data sekunder yang ditemukan, yakni menganalisis konten pada artikel yang memuat tentang data diri subjek, kemudian menganalisis kondisi fisik dan bahasa tubuh subjek melalui video yang ditemukan.

Berdasarkan sumber yang diperoleh, beberapa data yang dapat dianalisis yaitu:

1. Riwayat singkat orang tua subjek

2. Riwayat kelahiran dan perkembangan subjek dari usia 2 tahun hingga remaja

3. Prestasi subjek

4. Bahasa tubuh, kondisi fisik, serta proses interaksi subjek

5. Statemen orang-orang di dekat subjek 


\section{F. Hasil Dan Pembahasan}

\section{Biografi Singkat Ade Irawan}

Terlahir sebagai tunanetra di Colchester, Inggris, 15 Januari 1994. Putra pertama dari Irawan Subagyo dan Endang Irawan, sama-sama menjadi diplomat. Bakat musik Ade mulai tampak sejak usia 2,5 tahun, dan usia lima tahun, Ade bahkan sudah bisa memainkan sebuah lagu dangdut dengan menggunakan kibor mainan bernada lima oktaf. usia 9 tahun, Ade mulai menunjukkan minat khusus terhadap musik jazz.

Ade Irawan juga dikenal dengan Ade "wonder" Irawan, penambahan nama "wonder" itu pertama kali diberikan oleh Jaya Suprana dalam sebuah konser di Auditorium Bentara Budaya, Jakarta. Sebutan itu tidak lain karena kemiripan yang dimiliki oleh Stevie Wonder atau Julian Suresh Candiah, seorang tunanetra yang juga penyanyi, penulis lagu, produser rekaman, dan aktivis sosial Amerika yang telah memperoleh berbagai penghargaan seperti 21 penghargaan Grammy, juga sebuah piala Oscar untuk lagu terbaik dan masuk ke dalam Rock and Roll dan Songwriters Halls of fame.

Prestasi Ade, Juara lomba cipta lagu antarsekolah di Negara Bagian Illinois "Reflection" pada 2004-2007. Ade juga ikut dalam beberapa pertunjukan jazz seperti Chicago Winter Jazz Festival di Chicago Cultural Center pada April 2006 dan Januari 2007. Beberapa kali mengikuti audisi khusus dengan musisi jazz Amerika Serikat, seperti Coco Elysses-Hevia, Peter Saxe, Ramsey Lewis, John Faddis, Dick Hyman, Ryan Cohen, dan Ernie Adams, juga dia ikuti. Ade juga dipercaya sebagai pianis tetap pada acara musik Farnsworth School di Chicago dan pengisi tetap Jazz Links Jam Session (Jazz Institute of Chicago) di Chicago Cultural Center.

\section{Kerangka Berpikir Kasus Ade Irawan}

Untuk mempermudah pemahaman, berikut disajikan kerangka berpikir tentang analisis kasus Ade Irawan: 


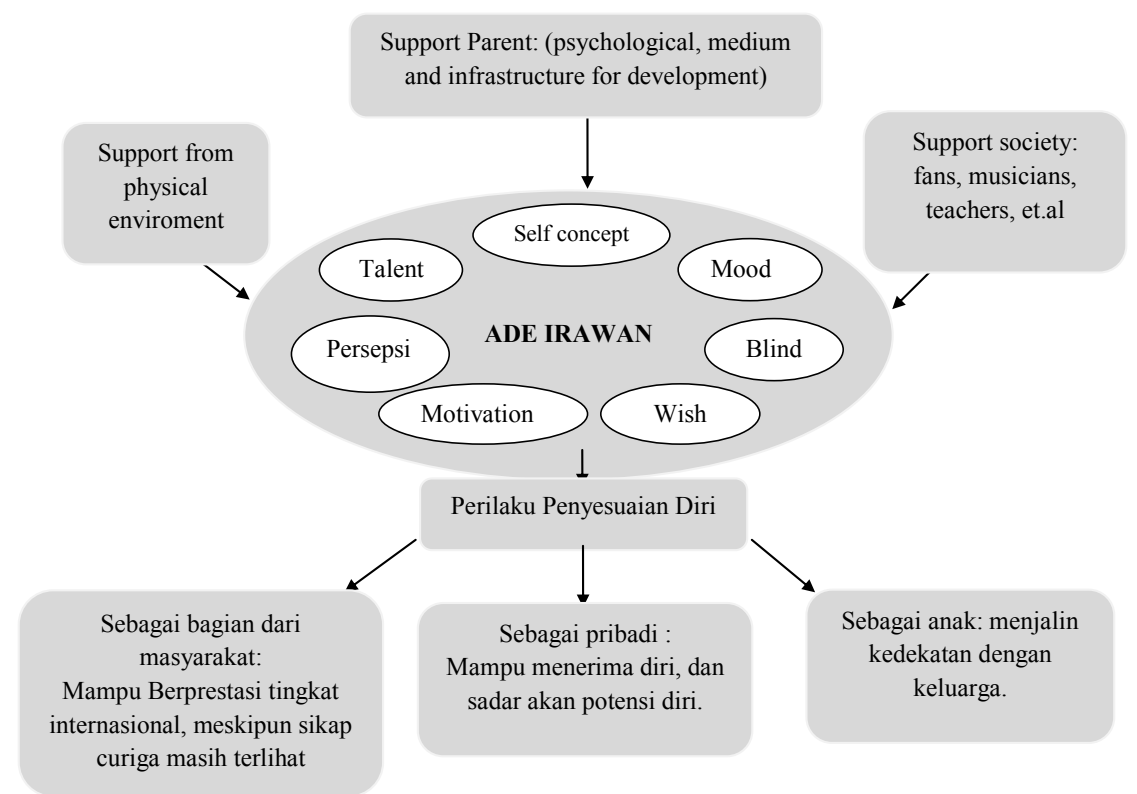

\section{Analisis Kasus Ade Irawan}

1) Proses Tumbuh Kembangnya Sejak Usia 2 Tahun Sampai Remaja

Lahir dari keluarga yang berpendidikan, dari pasangan Irawan Subagyo dan Endang Irawan, menjadi bekal utama Ade dalam melalui masa tumbuh kembangnya. Ade yang lahir pada 15 Januari 1994 di Colchester Inggris, telah dirangsang dengan pembentukan iklim dan lingkungan di Inggris.

Ade terlahir dalam keadaan buta total (blind) bukan sekedar low vision (kurang lihat) ataupun limited vision, mengalami proses pertumbuhan yang khas dibandingkan dengan bayi normal lainnya. Dimana setiap masa pertumbuhan dan perkembangan, setiap anak akan dihadapkan pada tugas-tugas perkembangannya. Gangguan penglihatan ini dapat dilihat dalam beberapa perkembangan awal di usia neonatal, seperti perkembangan sensori motorik di usia 0-2 tahun. (Jean Piaget, 1947: 123) 
Piaget menyebutkan bahwa perkembangan kognitif anak-anak pada usia 0-2 tahun hanya melalui sensori motoriknya. Bayi memperoleh pengetahuan tentang dunia dari tindakan-tindakan fisik yang mereka lakukan. Mengkoordinasikan pengalaman-pengalaman sensorik dengan tindakan-tindakan fisik. Seorang bayi berkembang dari tindakan refleksif, instingtif pada saat kelahiran hingga berkembangnya pemikiran simbolik awal pada akhir tahapan ini. (Jhon W. Santrock, 2007: 247) Piaget juga mempercayai bahwa di usia 4 sampai 5 bulan, saat bayi mulai mencoba meraih dan memegang benda. Kemudian pada usia 51/2 bulan mereka mulai berusaha menjangkau, memindahkan dan memutar benda tersebut. Segala kegiatan itu sangat tergantung pada panduan visual dimana mata memiliki fungsi utama untuk memandu gerakan tangan (anggota tubuh lain) (Papalia Old Feldman, 2009: 198).

Selanjutnya, pada usia 5 sampai 6 bulan anak akan mulai belajar merangkak dan berjalan. Jika pada anak awas pengenalan lingkungan rumah dan luar rumah tetap harus dengan pengawasan, maka pada kasus anak tunanetra dibutuhkan pengawasan ekstra. Dalam sebuah artikel di majalah Diffa disebutkan untuk melatih anak tunanetra merangkak dan berjalan harus dilakukan dengan cara orientasi dan mobilitas, artinya mengajarkan anak untuk mengenali lingkungan sekitarnya serta melakukan mobilitas dengan cara yang benar dan aman. (Majalah Diffa, 2010: 22)

Pada perkembangan sensori motorik, untuk belajar merangkak dan berjalan anak tunanetra membutuhkan stimulasi atau rangsangan yang kuat pada indra pendengaran dan indra peraba. Misalnya dengan cara mentitah, ibu memposisikan bayi berdiri lalu memegang tangannya (atau bisa juga dilakukan dengan kereta berjalan untuk anak). Dari depan bayi mintalah seseorang untuk membunyikan sesuatu. Saat mendengar bunyi tersebut bayi akan cenderung mencondongkan badannya ke depan dan ingin mendatangi sumber suara. Saat itulah ibu membantu bayi untuk menggerakkan kakinya dengan mendorongnya untuk maju. Selain itu, diperlukan juga tatanan ruangan yang aman dan menghindarkan perabotan rumah di ruang-ruang tertentu. Hal seperti ini harus dilakukan terus-menerus agar bayi dapat menghafal lingkungannya dengan baik. (Majalah Diffa, 2010: 22)

Pada prinsipnya pada usia neonatal penglihatan bayi belum berfungsi dengan baik namun hanya setengah dari bidang penglihatan 
orang dewasa, hal itu disebabkan oleh belum matangnya batang mata dan sel kerucut mata. Lemahnya otot bayi memang mengakibatkan ketidakmampuannya menangkap cahaya yang berbeda-beda dalam satu waktu. (Harlock, 1997: 63) Maka dari itulah bayi biasanya akan menangis untuk mengungkapkan segala hal yang ia butuhankan. Namun hal ini berbeda dengan kasus bayi yang terlahir dalam keadaan tunanetra seperti Ade, karena selamanya bayi akan tumbuh tanpa bisa melihat, menerima rangsangan melalui indra penglihatannya, serta menerima pengalaman-pengalaman yang akan membentuk dirinya nanti.

Dengan sudut pandang yang sama, lemahnya penglihatan yang dimiliki Ade tidak lantas menjadikannya bergantung pada orang lain, meskipun hambatan dalam perkembangan sensori motorik tetap ada, namun fungsi utama panduan visual telah digantikan dengan kepekaan pendengaran dan sensori yang jauh lebih baik kinerjanya daripada anakanak awas. Hal itu dibuktikan dari keahliannya dalam bermain musik. Bahkan di usianya yang baru 2,5 tahun, ia sudah mahir menirukan suara alat-alat musik dengan mulutnya. Bahkan di usia 5 tahun Ade sudah bisa memainkan sebuah lagu dangdut dengan menggunakan kibor mainan bernada lima oktaf.

Ade yang tidak pernah mengikuti les piano, dan cenderung belajar sendiri (otodidak), bisa sangat lihai memainkan kibor dan piano, bahkan beberapa jenis music yang terasah dengan baik, hanya melalui kepekaan pendengarannya. Selain perkembangan kognitif yang dialami bayi, kondisi orang tua pasca melahirkan juga berpengaruh pada kemampuan bayi dalam melakukan penyesuaian diri. Apalagi mendapati bayi yang telah dinantikan kelahirannya dalam keadaan cacat fisik, dipastikan orang tua akan mengalami tekanan emosi yang berakibat pada rasa kecewa dan gelisah, apalagi jika membayangkan masa depan yang akan dilalui oleh bayinya kelak. (Harlock, 1997: 58)

Stone mengemukakan ada berbagai faktor yang dapat mengganggu interaksi orang tua dan anak tunanetra, yaitu: (1) tidak adanya kontak mata antara orang tua dengan bayi, (2) minimnya kontak fisik orang tua dan bayi, (3) orang tua merasa bersalah karena merasa bertanggungjawab atas kecacatan anaknya, (4) perasaan trauma karena orang tua harus menghadapi reaksi prasangka dari orang-orang di sekitarnya, (5) perasaan tertekan dan cemas karena orang tua tidak tahu bagaimana cara memperlakukan dan mengasuh anaknya. (Stone, 1999) 
Kontak mata adalah bagian terpenting bagi orang tua dan bayi, terlebih ibu untuk saling mengenal. Namun meskipun penting, kontak mata bukanlah satu-satunya cara untuk saling mengenal antara orang tua dan anak. Pada kasus Ade ini misalnya, kedekatan antara orang tua anak berlangsung dengan baik, walau tanpa adanya kontak mata.

Secara rinci keadaan Endang (ibu Ade) pasca melahirkan memang tidak ditemukan dalam paparan artikel di atas, namun sepertinya Endang dan Irawan tidak butuh waktu lama untuk membangun penerimaan atas keadaan putranya. Dukungan psikis maupun fisik terlihat mendominasi masa pertumbuhan Ade.

\section{2) Support Parent}

Dukungan yang diberikan orang tua Ade memang terlihat jelas dalam kasus ini. Di tengah-tengah kesibukannya, Endang dan Irawan justru mampu mengenal anaknya dengan baik, mengikuti setiap masa pertumbuhannya dan memberikan apa yang dibutuhkan anaknya.

Kepedulian dan pemahaman yang tinggi tentang keadaan Ade memang sangat penting untuk mencapai keberhasilan penyesuaian diri. Mereka bahkan sedikitpun tidak ragu pada kemampuan yang dimiliki putranya. Mereka yakin bahwa di balik kekurangan fisik Ade, Tuhan akan memberkan satu keistimewaan dalam dirinya.

Selain konsep positif yang telah tertanam kuat dalam diri orang tuanya. Ditemukan juga berbagai budaya demokratis orang tua-anak yang terlihat dalam kasus ini, diantaranya orang tua Ade tidak menuntut Ade untuk berprestasi di sekolah. Sadar akan bakat dan keunikan yang dimiliki oleh putranya di bidang musik, kedua orang tuanya pun memberikan dukungan penuh pada pengembangan bakatnya di bidang music. Bahkan mereka membiarkan Ade berkembang dengan caranya sendiri, tidak memberikan paksaan atau bahkan ancaman, hal tersebut sesuai dengan apa yang diungkapkan oleh Endang berikut ini:

"Cara bermain Ade berbeda. Kalau dia ikut les piano, pasti nggak bakal lulus karena tekniknya pasti salah semua,"

Keluarga yang memiliki budaya mendidik demokratis seperti di atas akan memberikan pengaruh pada perkembangan kedewasaan pada anak. Pernyataan ini sesuai dengan apa yang disampaikan oleh 
Hurlock bahwa, anak yang dibesarkan dalam suasana rumah yang demokratis umunya mempunyai penyesuaian diri yang lebih baik dengan orang-orang di luar rumah daripada anak-anak dari suasana yang lembut dan otoriter. (Harlock, 1997: 130) Selain tingginya budaya demokrasi di keluarga ini, dukungan psikis lain juga diberikan sebesarbesarnya pada Ade.

Seiring dengan usianya anak-anak akan tumbuh dan berkembang, ia juga memiliki kebutuhan-kebutuhan yang akan selalu berkembang. Menurut Murray ada 20 kebutuhan manusia dalam kehidupan, diantaranya yaitu: (1) Kebutuhan akan berprestasi, (2) Kebutuhan akan eksibisi (menonjolkan diri), (3) Kebutuhan akan menghindari rasa hina. Dalam hal ini anak tunanetra juga memiliki tingkat kebutuhan yang sama dengan anak-anak awas. Mereka membutuhkan kesempatan meraih prestasi agar tidak ada perasaan terhina dimanapun mereka bergaul.

Pada tahun 2003, saat ditugaskan di Chicago Amerika Serikat, Endang dan Irawan justru memanfaatkan momen tersebut untuk mengenalkan Ade dengan music yang terkenal di dunia yaitu Jazz dan blues. Bahkan tidak tanggung-tanggung mereka juga rutin mengajak Ade untuk menikmati alunan music Jazz dan blues yang dimainkan oleh para musisi lokal dari kafe ke kafe.

Bahkan dalam satu kesempatan, mereka mendaftarkan Ade pada audisi yang diselenggarakan di kafe tertentu. Mulai dari membawakan kibor dari rumah, dilanjutkan dengan memasangkan kabel-kabel dan menata semuanya setibanya di kafe tempat penyelenggara audisi. Dalam satu statemen Endang menyatakan,

"Saat itu kami bukan lagi diplomat, tapi kami adalah pendukung Ade".

Kondisi yang seperti itu jelas akan membentuk penyesuian diri yang positif bagi Ade. Titin Andri Wihastuti dalam sebuah jurnal menjelaskan bahwa, beberapa faktor yang mempengaruhi penyesuaian diri adalah (1) keadaan fisik, (2) perkembangan dan kematangan, (3) keadaan psikologis, (4) keadaan lingkungan, (5) serta tingkat religiusitas dan kebudayaan. (Wihastuti, 2)

Maka dalam proses penyesuaian diri Ade, ada berbagai faktor yang mempengaruhinya, namun fisik justru bukan penghambat proses 
penyesuaian diri itu. Lingkungan yang telah membentuknya dengan cukup baik, akan menjadi faktor utama dalam proses penyesuaian diri positif yang ia lakukan.

Hal tersebut dapat dibuktikan dari 4 tahun berjalan sejak 2003 hingga 2007, dimana ia berhasil meraih berbagai prestasi diantaranya juara lomba cipta lagu antarsekolah di Negara Bagian Illinois "Reflection" pada tahun 2004-2007. Sepanjang tahun itu pula, Ade telah mengikuti berbagai pertunjukan seperti Chicago Winter Jazz Festival di Chicago Cultural Center pada April 2006 dan Januari 2007.

Bahkan ia juga mengikuti audusi khusus dengan musisi jazz Amerka Serikat, seperti Coco Elysses-Hevia, Peter Saxe dan beberapa musisi lainnya. Ia juga dipercayai sebagai pianis tetap pada acara music Farnsworth School di Chicago, dan menjadi pengisi tetap Jazz Links Jam Session (Jazz Institute Of Chicago Cultural Center). Akses untuk menyalurkan bakat memang diberikan seluas-luasnya oleh orangtua Ade.

Jika ditelaah, selama rentang waktu itu, di usianya yang masih tergolong muda Ade telah bertemu dengan banyak orang, bahkan kebanyakan dari mereka adalah para musisi hebat yang memiliki banyak pengalaman di bidang itu. Dapat dipastikan ada berbagai aktivitas yang dapat dijumpai dalam kesempatan ini. Ada pola-pola interaksi, seperti rasa hormat, tanggungjawab, rasa rendah diri yang pasti dialami Ade. Proses penyesuaian diri seperti inilah yang akan membentuknya menjadi seorang pribadi yang menarik.

Pada dasarnya pada anak usia 0-5 tahun keluarga memiliki pengaruh yang sangat besar pada pembentukan dirinya. Penyesuaian diri anak di usia ini sangat dipengaruhi oleh hubungannya dengan orang tua di masa awal kanak-kanak. Anak akan cenderung meniru sikap, emosi dan pola perilaku salah seorang dari kedua orang tuanya yang paling ia sayangi. (Harlock, 1997: 130) Sikap Ade di atas, pastilah cukup dipengaruhi oleh masa-masa ini.

\section{3) Intelegensi}

Dalam hal ini, Utami Munandar menilai bahwa keberhasilan penyesuaian diri seseorang tergantung dari kemampuannya untuk berpikir dan belajar. Sejauh mana ia mampu memahami pengalamanpengalamannya. Seperti setiap proses dalam cara mereka mengungkapkan 
pikiran, cara berbicara, cara mengajukan pertanyaan, kemampuan memecahkan masalah, dan sebagainya yang dapat mencerminkan kecerdasan. (Munandar, 1992: 19)

WilliamStern mengemukakan bahwa intelegensi adalah kesanggupan untuk menyesuaikan diri kepada kebutuhan baru, dengan menggunakan alat-alat berpikir yang sesuai dengan tujuannya. (Purwanto, 1985: 54) Dari beberapa hasil penelitian yang telah dilakukan, rentang intelegensi seseorang dipengaruhi oleh dua hal yakni faktor hereditas (gen) dan faktor lingkungan. (Azwar, 2006: 66)

Dalam kasus ini meskipun ending dan Irawan sama sekali tidak berbakat di dunia music, namun dalam diri Ade terlihat mewarisi beberapa sifat dan watak yang ada dalam diri kedua orang tuanya, diantaranya mau berjuang, dan mudah bergaul dengan banyak kalangan untuk mengembangkan dirinya.

4) Kecerdasan Musik dan hubungannya dengan Pembentukan Konsep Diri Positif

Beberapa jurnal penelitian memang telah menyatakan bahwa music memiliki pengaruh positif yang cukup baik untuk perkembangan anakanak berkebutuhan khusus. Aktivitas bermusik juga memungkinkan ABK memperoleh kepercayaan diri, harga diri dan motivasi untuk hidup lebih baik.

Secara khusus manfaat musik bagi anak, khususnya yang berada di bawah usia tiga tahun dijelaskan oleh Ortiz (2002:86) yakni: (1) Mampu memotivasi anak untuk berlatih, (2) meningkatkan kepekaan tubuh, (3) mengaktifkan tumbuhnya keterampilan motorik kasar, (4) meningkatkan koordinasi, (5) mengembangkan rasa percaya diri, (6) bertindak sebagai katalis untuk improvisasi, (7) memperkenalkan dan mempertahankan struktur dalam kegiatan yang teratur, (8) berfungsi sebagai sumber kebahagiaan dan kesenangan, (9) mendorong terjadinya hubungan sosial dan menciptakan lingkungan yang terkendali dimana pengungkapan diri bisa diwujudkan.

Dari berbagai manfaat di atas jika dikaitkan dengan kasus Ade, meskipun memiliki gangguan visual, namun Ade bisa menjadi lebih unggul dari anak awas lainnya. Motivasi yang besar untuk terus mengembangkan kemampuannya dalam bermain piano tampak sangat 
jelas dimiliki Ade. Dalam salah satu perbincangan di kick Andy, Ade terlihat sangat percaya diri, saat berbicara ia tidak terlihat takut ataupun berkecil hati di hadapan semua penonton, ia mengangkat wajahnya dan tidak menunduk malu sama seperti orang yang awas pada umumnya Kepekaan tubuh dan pengembangan motorik kasar juga terlihat dalam diri Ade saat memainkan nada-nada kibor, jari-jarinya nampak bergerak cepat mengusai setiap not. Dari penjelasan tersebut diperoleh pemahaman betapa cerdasnya Ade dalam bermain music. Hal itu dapat dilihat dari gambar berikut ini:

\section{Music on the mind}

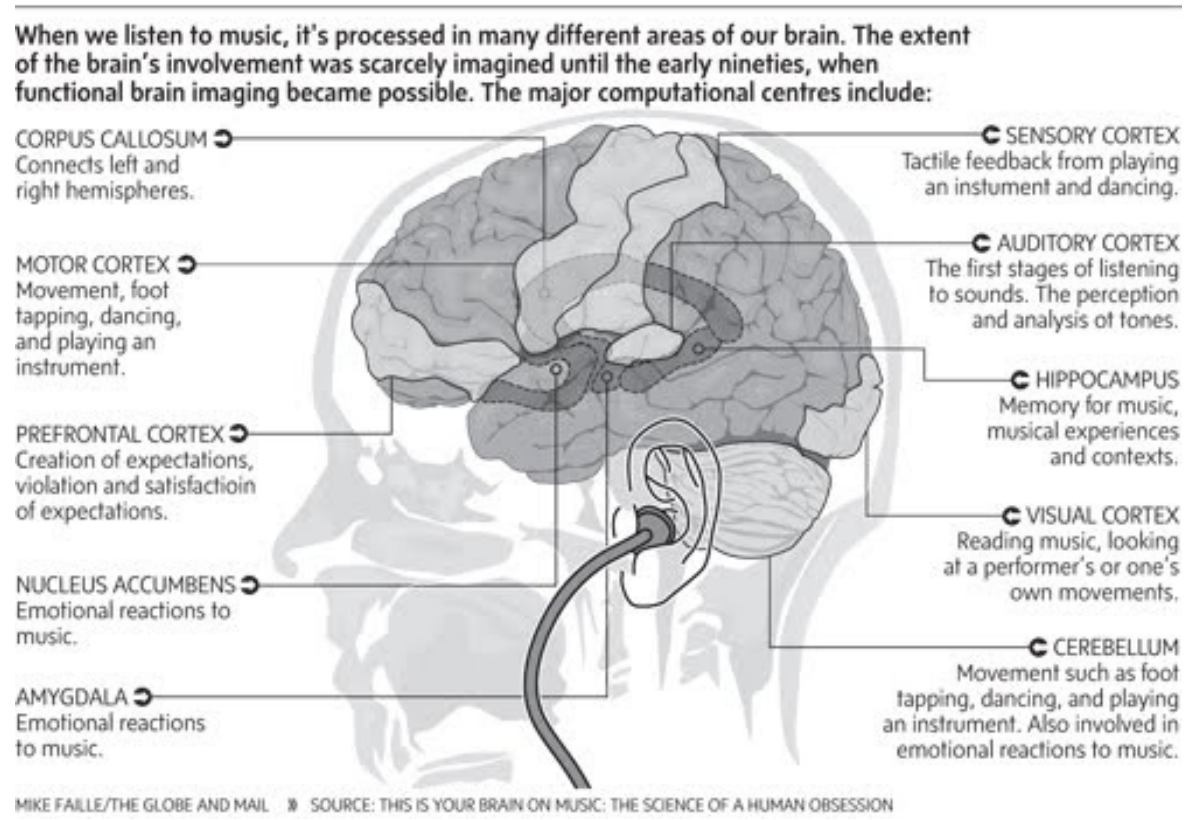

Dari gambar di atas, dapat dilihat ada ada 10 bagian di dalam otak yang turut bereaksi saat seseorang menyimak musik. Sepuluh bagian tersebut yaitu: sensory cortex, auditory cortex, hippocampus, visual cortex, cerrebellum, amigdala, nucleus accumbens, prefrontal cortex, motor cortex dan corpus collosum. Dan bagian-bagian tersebut telah terjadi pada diri Ade.

Jika Abraham Maslow dalam teori piramida kebutuhan menyatakan bahwa kebutuhan tertinggi setiap manusia adalah kebutuhan 
mengaktualisasikan diri, yang ditandai dengan sikap yang mandiri, menolak tekanan sosial, mencintai kebebasan. (Howard Friedman dan Miriam, 2006: 355) Kebutuhan ini pun tidak ada pengkhususan untuk anak normal atau pun yang mengalami gangguan, dalam artian semua manusia memiliki kebutuhan yang sama dalam mengaktualisasikan dirinya. Dalam kasus Ade, aktualisasi diri yang telah ia dapatkan dalam bidang musik terekam dengan baik. Melakukan hobi di depan banyak orang, dan mendapatkan reson positif sangatlah penting bagi perkembangan setiap diri individu, dan Ade telah berkali-kali memperolehnya, mulai dari tepuk tangan, sanjungan, pengakuan, serta beberapa juara dan penghargaan yang ia terima baik di dalam ataupun luar negeri, hal ini jelas akan membangun banyak hal positif dalam dirinya, meskipun ia seorang tunanetra sekalipun. Keadaan ini setidaknya menjawab apa yang telah disampaikan Alferd Adler bahwa: (Diana, 2011: 166)

Anak-anak yang dilahirkan dalam keadaan cacat fisik yang berat memiliki resiko stress lebih besar dan hambatan dalam penyesuaian diri. Hal itu dikarenakan mereka harus mampu mengkompensasi kekurangan-kekurangannya, dan berakibat pada rendahnya rasa percaya diri, lemahnya keberanian dan lebih sensitive (mudah tersinggung) terhadap sikap orang lain.

Burn juga menyampaikan hal yang senada; kepemilikan konsep diri yang positif pada remaja pada umumnya (termasuk remaja tunanetra), akan cukup dipengaruhi oleh tingkat kematangan fisik. Pertumbuhan fisik yang kurang maksimal (seperti pada anak-anak normal lainnya) akan menjadi sumber kecemasan pada anak-anak tunanetra dalam melakukan penyesuaian diri. (Burn, 1993: 198)

Di usianya yang telah memasuki usia 20 tahun, sebagai penyandang cacat Ade berkembang dengan baik, kematangan fisik dan kematangan psikis dimilikinya. Ia mampu mengalahkan rasa rendah diri (down) di hadapan seluruh masyarakat. Meskipun dalam artikel disebutkan bahwa Ade adalah sosok yang fleksibel, dalam satu keadaan ia terlihat diam, bahkan menjawab pertanyaan dengan sangat singkat bahkan hanya dengan senyum, namun disebutkan juga sesekali Ade menyuguhkan sikap yang humoris. Kedekatan dengan ibunya tidak bisa ditutupi, hal tersebut terlihat jelas karena Adesangat senang bercerita pengalamannya, bahkan saat duduk di kelas X SMA ia berani bercerita telah menaruh perasaan senang pada teman lawan jenis pada ibunya. 
Disebutkan ada beberapa karateristik umum anak tunanetra yaitu: (1) Cenderung mengembangkan rasa curiga terhadap orang lain, (2) Perasaan mudah tersinggung, (3) Mengembangkan verbalisme, (4) Mengembangkan perasaan rendah diri, (5) Mengembangkan adatan "blindism/mannerism", (6) Suka berfantasi, (7) Berpikir kritis, (8) Pemberani, (9) Ketergantungan yang berlebihan. (Sari Rudiyati, 2002: 34-37)

Pada diri Ade, juga dijumpai perasaan waspada pada orang baru yang belum pernah ia kenal, seperti disebutkan caranya menjawab pertanyaan dengan hanya senyum dan tidak banyak bicara. Namun sikapnya ini tergolong wajar seperti beberapa orang normal yang juga memilih menutup diri pada orang yang baru saja ia kenal. Terlebih jika mengingat kemampuannya berinteraksi secara baik dengan para musisi senior yang ditemuinya saat di Amerika.

Beberapa karakter lain yang cenderung negative tidak ditemukan dalam diri Ade, seperti perasaan rendah diri, mengembangkan adatan, dan memiliki ketergantungan yang berlebihan pada orang lain. Karakter positif yang ditemui adalah sikapnya yang pemberani dan berpikir kritis.

\section{G. Kesimpulan dan Saran}

Berdasarkan hasil analisis kasus yang telah dilakukan, ada beberapa hal yang dapat disimpulkan adalah Perkembangan Ade Irawan melalui proses yang cukup baik, hal tersebut dapat dilihat dari (1) adanya dukungan orangtua (support parent), (2) tingginya tingkat intelegensi yang dimiliki, (3) bakat music, membentuk positive self concept, (4) alih fungsi viasualisasi dengan audio sebagai indra dominan, (5) karakter umum tunanetra: sikap waspada yang tinggi pada orang baru, pemberani dan kritis.

Sebagai bentuk rekomendasi untuk para peneliti selanjutnya, yang tertarik untuk melakukan penelitian tentang tunanetra, dapat dilakukan uji coba untukmelihat kondisi anak tunanetra yang mendapatkan perilaku sebaliknya, tidak ada support parent, tingkat intelegensi baik karena pengaruh genetik maupun karena adanya motivasi internal tunanetra Agar diperoleh kesimpulan yang saling menguatkan penelitian sebelumnya tentang masalah penyesuaian diri tunanetra. 


\section{DAFTAR PUSTAKA}

Adzim, Ahmad, 2006, Penelitian Skripsi: Perbedaan Konsep Diri Penyandang Cacat Fisik Bawaan Dengan Penyandang Cacat Fisik Bukan Bawaan Di Yaketunis Kotamadya Yogyakarta, (UIN Suka Yogyakarta: Tidak diterbitkan)

A. Kirk,Samuel et.al, 1991, Pendidikan Anak Luar Biasa, (Bandung: Program Studi Pendidikan Luar Biasa FKIP Universitas Islam Nusantara Bandung)Burn, R. B, 1993, Konsep Diri: Theori, Pengukuran, Perkembangan \& Perilaku, (Jakarta: Arcan).

Azwar, Saifudin, Pikologi Intelejensi Cetakan 1, (Yogyakarta: Pustaka Pelajar, 2006)

Burn, R. B, 1993, Konsep Diri: Theori, Pengukuran, Perkembangan $\mathcal{E}$ Perilaku, (Jakarta: Arcan)

Desmita, 2005, Psikologi Perkembangan. (Bandung: PT Remaja Rosdakarya).

Diana, R. Rachmy, dkk, 2011, Jurnal Penelitian Psikologi Vol. 2 No. 1: Konseling Kelompok KognitifSpiritual \& Penyesuaian Diri Mahasiswa Difabel Tunanetra, (Surabaya: IAIN Sunan Ampel)

Feldman, Papalia Old, 2009, Human Development.,. terj. Brian Marswendy, Perkembangan Manusia, (Jakarta: Salemba Humanika)

Friedman, Howard, et.al, 2006, Psikologi Kepribadian, (Erlangga: PT Gelora aksara Pratama).

http://id.wikipedia.org/wiki/Stevie_Wonder

http:/ / repository.usu.ac.id/bitstream/123456789/20149/4/ Chapter\%20I.pdf,

http://file.upi.edu/Direktori/FPBS/JUR._PEND._SENI_MUSIK, http://www.youtube.com/watch?v=pgXgRozmIXE

Hall, C.S, \& G. Lindzey. 2005, Psikologi Kepribadian 2: Teori-teori Holistik. (Yogyakarta: Penerbit Kanisius)

Harjaningrum, Agnes Tri, dkk, 2007, Peranan Orang Tua dan Praktisi Dalam Membantu Tumuh Kembang Anak Berbakat Melalui Pemahaman Teori dan Tren Pendidikan, (Jakarta: Prenada Media 
Group).

Kirk, Samuel A., et.al, 1991, Pendidikan Anak Luar Biasa, (Bandung: Program Studi Pendidikan Luar Biasa FKIP Universitas Islam Nusantara Bandung).

Majalah Diffa Edisi Oktober 2010: Mengajari Anak Tunanetra Berjalan

Munandar, S. C Utami, 1992, Mengembangkan Bakat Dan Kreativitas Anak Sekolah, (Jakarta: PT Gramedia Widiasarana Indonesia).

Nelson, Ricard, et.al, 2011. Teori dan Praktik Konseling dan Terapi, (Yogyakarta: Pustaka Pelajar).

Piaget, Jean, 1947, The Psychology Of Intelligence, (France: Great Britain)

Purwanto, M. Ngalim, 1985, Psikologi Pendidikan, (Bandung: Remadja Karya)

Rudiyati, Sari, 2002, Pendidikan Anak Tunanetra: Buku Pegangan Kuliah, (Yogyakarta: Fakultas Ilmu Pendidikan, Universitas Negeri Yogyakarta).

Sari Rudiyati, Pendidikan Anak Tunanetra: Buku Pegangan Kuliah, (Yogyakarta: Fakultas Ilmu Pendidikan, Universitas Negeri Yogyakarta, 2002)

Semiun, Yustinus, 2006, Kesehatan Mental 2, (Yogyakarta: Kanisius).

Siti Chalidah, Ellah, 2005, Terapi Permainan Bagi Anak Yang Memerlukan Layanan Pendidikan Khusus, (Jakarta: Departemen Pendidikan Nasional DIKTI).

Santrock, Jhon W. 2007, Child Development, Eleventh Edition., terj. Tim Penerbit Erlangga. Perkembangan Anak Edisi 20. (Jakarta: Erlangga).

Soejono, Abdurrrahman, Metode penelitian Suatu Pemikiran dan Penerapannya, (Jakarta: Reneka Cipta, 1999)

Stone J, 1999. "The Pre-school Child”, dalam Mason, H. \& McCall, S. (Eds.). (1999). Visual Impairment: Access to Education for Children and Young People. London: David Fulton Publishers) 
Suhaeni HN, dan Purwanta, Edi, Bimbingan Konseling Anak Luar Biasa, (DIKTI, proyek penddidikan tenaga guru: tidak diterbitkan)

Susanandari, Dwi Ajeng, 2009, Gambaran Penyesuaian Diri Ibu dan Perkembangan Kemampuan Anak Tunaganda-Netra, (FPsi. Universitas Indonesia: tidak diterbitkan).

Tirtonegoro, Sutratinah, 1984, Anak Supernormal dan Pendidikannya, (Jakarta: Bina Aksara).

Widdjajantin, Anastasia dan Imanuel Hitipeauw, Ortopedagogik Tunanetra I, (Departemen Pendidikan dan Kebudayaan Direktorat jenderal Pendidikan Tinggi Proyek Pendidikan Tenaga Guru, tidak diterbitkan).

Wihastuti, Titin Andri, dkk, 2013, E-Jurnal Kesehatan: Hubungan Dukungan Keluarga Dengan Kemampuan Penyesuaian Diri Pada Anak Retardasi Mental Tingkat Sedang (Embsil) Di SLB Pembina Tingkat Nasional Bag. CMalang, (Fakultas Kedokteran Universitas Brawijaya Malang: Tidak diterbitkan). 